\title{
遺伝子トラップ法による 遺伝子破壊マウス作製技術
}

要約：ヒトゲノムプロジェクトの進展により種々の生 物のゲノムの塩基配列は明らかとなったが, 塩基配列 のみでは，遺伝子およびコード領域以外の部分がどの ような機能を持っているのか推定すらできないし，ま た遺伝子自身の機能に関する情報も不十分である.こ のため全長 cDNA 配列の決定, DNA チップによる発 現パターンの解析, タンパクの構造解析, タンパクに 対する抗体作製等の機能解析系が必要であるといわれ ている.しかし，これらは重要ではあるが，あくまで 機能を同定するための状況証拠を提供するにすぎない とみるべきである，具体例を一つあげれば， Cbfa1 は， リンパ球で発現する遺伝子の転写因子として発見され たが，その破壊マウスでは骨形成がみられず，骨形成 のマスター遺伝子であることが分かった。このことは, 構造や発現パターンからだけでは, 必ずしも機能は推 測できないことを示唆している，そこで，遺伝子改変 マウスを用いた in vivoの解析の重要性が再認識され, 欧米でノックアウトマウスプロジェクトが始まり, 合 計すれば年間約 40 億円に達する金額が投じられるこ ととなった. その内容は, 遺伝子トラップ法や相同組 換え法を用いてほぼ網羅的にノックアウト ES クロー ンを取るプロジェクトであるが，当面は 129 系統由来 の $\mathrm{ES}$ 細胞を用い, やがて確立されれば $\mathrm{C} 57 \mathrm{BL} / 6$ 由 来の $\mathrm{ES}$ 細胞を用いて行うというものである. 筆者ら は網羅的遺伝子破壊を目指して, 可変型遺伝子トラッ プ法を開発した。この方法により, 第 1 段階で完全破 壊が, 第 2 段階でトラップベクター内のマーカー遺伝 子を, 別の遺伝子で置換, 第 3 段階で条件的遺伝子破 壊が可能となった。やがて, 遺伝子破壊された ES 細 胞が全世界に配られ，遺伝子破壊マウスが多量に作製 され, 保存される時が来る. 熊本大学生命資源研究支 援センターでは, 世界の主要なリソースセンターが参
加し，保存と供給の支援を行う FIMRe（Federation of International Mouse Resources）にも創立メンバーと して参加し，また，アジアに扔けるミュータジェネシ スとリソースセンターの連合体である AMMRA(Asian Mouse Mutagenesis and Resource Association) も立 ち上げ，今後の対応も視野にいれた活動を行っている.

\section{1. 変異マウス作製法}

変異マウスの作成法は, 大きく分けて 2 つり, 自 然突然変異と誘発突然変異とがある. 自然突然変異は, 飼育中に偶然に発見する変異で, 古典的ではあるが, 過去 1000 種類ほどが知られており，この中にはヌー ドマウスや NOD マウス等があり, 貢献度の高いマウ スも存在する。誘発変異には, 放射線や変異原物質に よる方法, 相同組換え法, 遺伝子トラップ法がある. 放射線では，久失等の大きな変異が生じることが多い が, ENU (ethylnitroso urea) 等の変異原物質では, 点突然変異が生じる。ENUを用いたミュータジェネ シスが 1997 年にドイッで始まり，英国，米国，わが 国でも始められたが，現在ほぼ収束に向かっている。 相同組換え法は, 別項で述べられるので省略する, 遺 伝子トラップ法は, 以下に述べる.

\section{2. 遺伝子ノックアウトの歴史}

歴史を振り返ると, 実は古くから方法論が発達して きている．相同組換えについては，1981 年の ES 細胞 の樹立が始まりで，1984 年に ES 細胞を用いて作製し たキメラマウスから初めて生殖系列への伝達が認めら れている. 1985 年には Smithies らによる培養細胞で の相同組換えが，1987 年には Capechi らによる ES 細 胞での相同組換えが報告された。そして，1989年に $\mathrm{ES}$ 細胞を用いた遺伝子破壊マウスの誕生が始めて報

キーワード：遺伝子トラップ, ノックアウトマウス, ミュータジェネシス, ES 細胞, 遺伝子置換

熊本大学 発生医学研究センター（テ860-0811 熊本市本荘 2-2-1）

e-mail: yamamura@gpo.kumamoto-u.ac.jp＼cjkstart原稿受領日 : 2007 年 1 月 29 日，依頼原稿

Title: Production of knockout mouse by gene trapping. Author: Ken-ichi Yamamura 
告された。

一方，遺伝子トラップ法については，1978 年に大 腸菌で，転写が活性化されている領域を見つけるエン ハンサートラップ方法として開発されたのが最初であ る(1)。ついで，これが培養細胞に応用されたのが， 1983 年である (2)。このあたりまでは，遺伝子を発見 する方法として使われている. 1987 年には， ショウ ジョウバエ個体に応用され，遺伝子を発見するととも に遺伝子を破壊する方法として用いられた(3)。翌 1988 年にはマウス受精卵を用いてエンハンサーを見 つける方法が報告されたが $(4,5)$, 哺乳類ではエンハ ンサーが必ずしもコード領域の近くにないこと，受精 卵を用いたのでは効率が悪く, なかなか遺伝子を発見 できないことから，1989 年には ES 細胞を用いた遺伝 子トラップ法が開発された (6).

\section{3. 遺伝子トラップ法}

遺伝子トラップ法には，原理的には 4 種類ある（図 1). 第 1 は, エンハンサートラップ法であり, この場 合は弱いプロモーターとマーカー遺伝子とポリ A を もつ構造となる. 第 2 は, プロモータートラップ法で あり，プロモーターを持たないが，ポリ A を持つマ 一カー遺伝子を用いる。第 3 は, エクソンノイントロ ントラップで，この場合はスプライスアクセプターを マーカー遺伝子につなぎ，ポリ A もつけておく. 第 4 は，ポリ A ラップベクターで, 弱いプロモーター とマーカー遺伝子だけの構造である。しかし，当初考 案されたポリAトラップベクターでは, 機能しない ことが明らかになった。 その理由は, マーカー遺伝子 のポリ A が，トラップした遺伝子のポリ Aより 50 60 塩基対より上流にあると, いわゆる nonsense mediated DNA decay（NMD）が起こり, mRNAが破壞

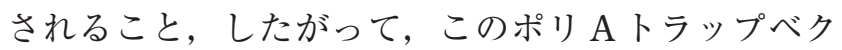
ターでは，遺伝子の上流にトラップベクターが入った

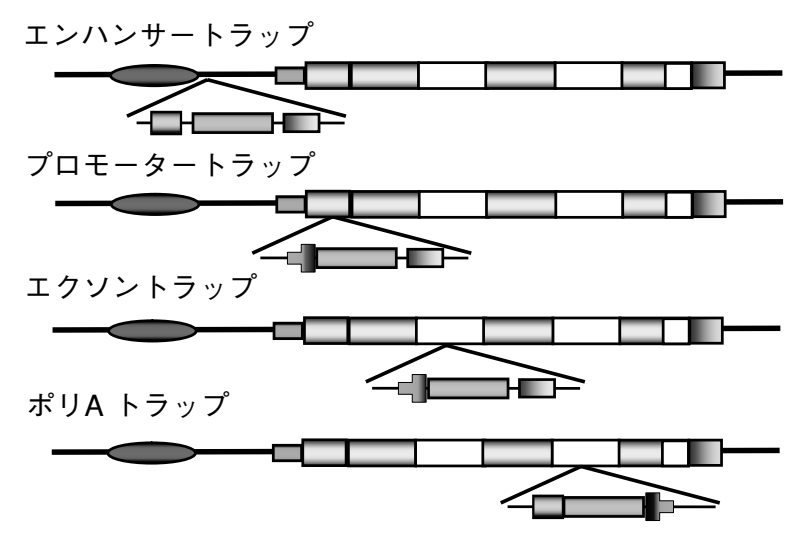

図 1 遺伝子トラップ法
場合は，クローンとして取れないことがわかったから である．現在は，IRESを抻入することにより，NMD を回避できるべクターが開発されている $(7)$.

\section{4. 可変型遺伝子トラップ法}

筆者らは, 単なる遺伝子機能の解析ではなく, ゲノ ム医学のためのヒト疾患モデルマウスの作製，あるい はゲノム創薬の展開のためのモデル作製も可能な方法 論の開発を行った。このためには，ひとつの遺伝子あ たり 10 個の異なった変異を導入し, 解析する必要が あると考えられている。そこで, 遺伝子をトラップし た後に, 興味ある遺伝子を挿入し, 必要に応じて条件 的に遺伝子破壊ができる方法論の開発が必須である. あとで興味ある遺伝子を挿入したとき，トラップした 遺伝子の一部分が発現すると，そこから翻訳された夕 ンパクが何らかの機能, たとえばドミナントネガティ ブに働くタンパク，を持ってしまうことも予想される。 そこで, 内在性遺伝は完全に破壊する必要が生じる。 そこで, プロモータートラップベクターにすることと した。このため, IRESを用いないこと，また，マー カー遺伝子の上流に停止コドンが来るようにした。こ のようなべクターであれば，もし遺伝子の途中に組み 込まれたとしても，上流からの翻訳は停止コドンで終 了し, マーカー遺伝子内の薬郕耐性遺伝子であるネオ も発現しないことになる，つまり，このようなクロー ンが，ネ才選択しても取れてこないことになる。した がって, プロモーター付近にベクターが挿入され, 正 しくネオが発現するクローンのみが単離できることに なる，さらに，いったん遺伝子を完全破壊したあと， 遺伝子置換を行うため, つまり beta-geo 部分を他の 遺伝子等に置換するため, 上流に $\operatorname{lox} 71$ を, 下流に loxP-polyA-lox 2272 を挿入した。この lox71や lox2272 は，10xP 配列の反復配列部分またはスペーサ 一領域に変異をもつものである。これを用いた理由は 次のとおりである. Cre-loxP システムは, 大腸菌内 では切り出しと挿入反応が観察されるが, 哺乳類細胞 では核の体積が大きいので，いったんCreにより切 り出された断片が, Cre とともにゲノム上の loxPの 近傍に存在することは物理的に困難で，そのため挿入 反応は結果として殆ど観察されていない。 そこで挿入 するための方法として, loxP 配列に変異を挿入し, いったん挿入されれば削除ができなくなるように改変 することを試みた。原理は，次のようなものである. まず，左端の反復配列に変異を導入した lox 71 と，右 端に変異を導入した lox66 準備する. 1ox71 は細胞 に導入しゲノム上に組み込んでおく。挿入したい 
DNA を含むプラスミド上に lox66 を組み込んでおく。 Cre と lox66 を含むプラスミドを, 細胞にエレクトロ ポレーションすると左端に変異を有する lox71 と右端 に変異を有する 10x66の間で組換えが起こり挿入され る。いったん挿入されると，左側には左端および右端 とも変異をもつ lox71/66 が，右側には正常の loxPが 配列することになる. Cre は, 両端に変異をもつ 10x71/66 を認識する効率が悪く，したがって，削除 の反応の効率が悪くなり挿入されたままとなる。筆者 らは $\mathrm{ES}$ 細胞に応用し，10\%程度の効率で挿入された クローンが単離できることを明らかにした，その後， loxP あるいはスペーサー部分に変異を持つ lox 2272 を 利用することにより, lox71 と loxP または lox2272で はさまれた部分のみを入れ替えることも可能であるこ とを明らかにした。この変異型 lox を利用したトラッ プベクターを作製し pU17 と命名し，それを用いた方 法を可変型遺伝子トラップ法と命名した (図 2) (8-10).

\section{5. 世界のノックアウトマウスプロジェクト}

\section{1）現状}

これまで $\mathrm{ES}$ 細胞を用いた「個々の」遺伝子破壊マ ウス作製は大きな威力を発揮し, その機能解析のため の「戦術」として用いられてきた。しかし，個々の研 究室でこの方法を用いて遺伝子破壊マウスを作製する と, 膨大なコストと労力と時間が必要であるという久 点がある．例えば，1系統の破壊マウス樹立には最低 500 万円かかるとしても，3 万個の遺伝子については 1,500 億円必要である.この方法による律速段階は ES 細胞を用いた相同組換えであり，世界中で作製されて
いる遺伝子破壊マウスの数は多くても 1 年間約 1,000 系統であり,これだと 30 年かかることになる。 そこで, 集中的に大規模に突然変異マウスを「網羅的」に作製 する構想が浮上した。つまり, マウス変異体作製がこ れまでの「戦術」から「戦略」目標となったのである。

現在，世界では 3 つのプロジェクトが始動した。第 1 は, EU の EUCOMM プロジェクトである (11)。遺 伝子トラップ法と相同組換え法を併用し，20,000 個の 遺伝子破壊 ES クローンを取る, 3 年間で 1300 万ユー ロの計画である。第 2 は, カナダの NorCOMM プロ ジェクトで，主に遺伝子トラップ法を用い 4 年間で 840 万カナダドルのプロジェクトである。第 3 は，米 国の KOMP プロジェクトであり (12)，5 年間で 5200 万ドルで, 相同組換え法のみで, 約 8000 の遺伝子破 壊 $\mathrm{ES}$ クロンを取る予定である。 さらに，中国でも 3 年間で 1 億中国元でのプロジェクトが始められるこ とが決定された。世界中の予算を合計すると，年間約 40 億円のプロジェクトとなる、筆者らも, 我が国の プロジェクトの必要性を叫んでいるが，まだ実現して いない. 早く始めないと，日本は何の貢献もできない ことになる．

\section{2）ノックアウトプロジェクトの理念と思想}

理念は, 生命科学の全領域における研究推進であり, リサーチのためのリソースの創出であり，個人の利益 ではなく公の利益のためである。したがって，このプ ロジェクトは大規模で網羅的でなければならず，それ ゆえ国家プロジェクトとして実施し, 成果は共有する という思想が必要である。 また，世界でプロジェクト が進行する中で，我が国が影響力を発揮でき，発言権

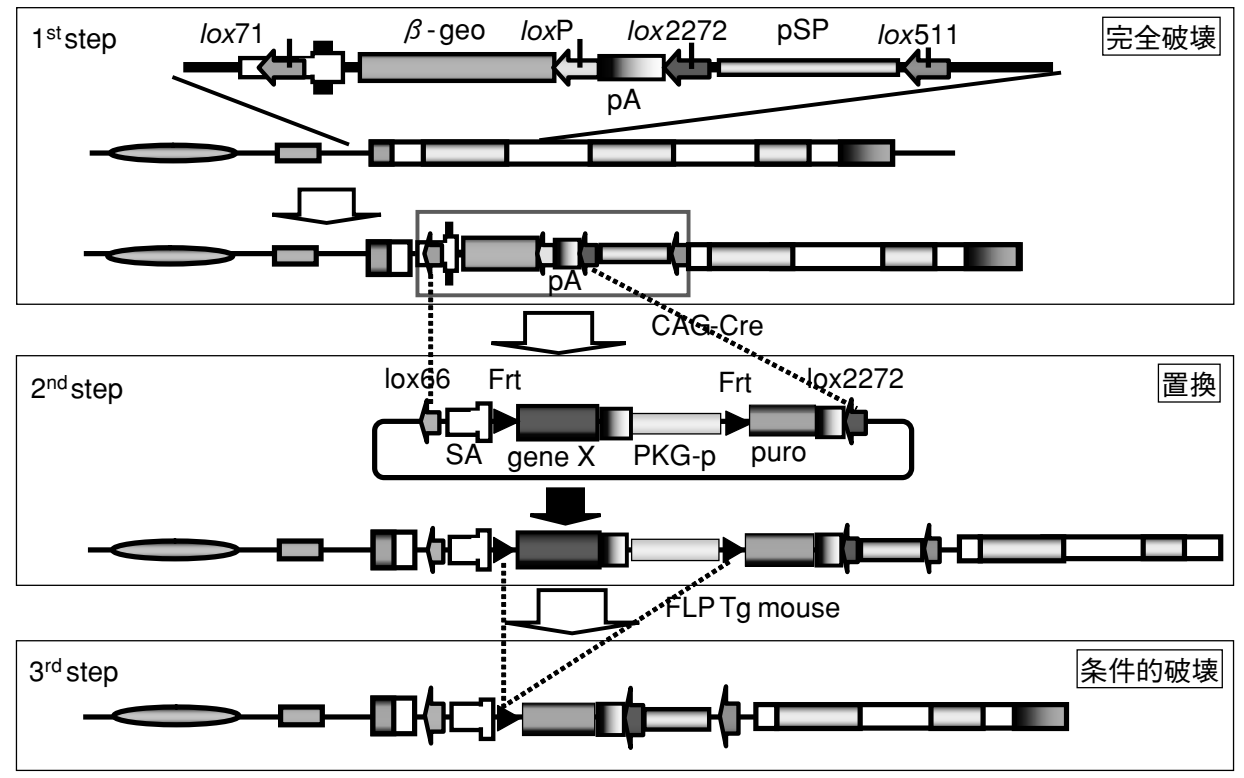

図 2 可変型遺伝子トラップ法 
を確保できるリソースを持つ必要がある.

3）必要性

ヒトゲノムプロジェクトにおいて，我が国は $8 \%$ の ゲノムの塩基配列を決定した.ゲノムの塩基配列の決 定により，多額の研究費を持たず自ら塩基配列の決定 を大規模に行えない研究者にとっても，大きく研究を 推進させることができている．遺伝子破壊マウスから 得られる情報は，非常に多大であるが，そのコストが 高いゆえ, 誰でも可能ということではない. 多くの研 究者が行いたくてもできない状況にある。したがって, 個々の研究者にとって，大きな価值がある。ばらばら に進めれば，同じ遺伝子を複数の研究者が作製すると いう重複が生じるし，コスト，労力，時間が無駄にな る.ささらに，研究者は遺伝子破壊マウスを作製するこ とが仕事ではなく，それを解析して新しい発見をする ことであるので, 遺伝子破壊マウスの作製に時間を取 られることがなくなれば，それだけ解析に集中でき， 研究が進展する.

\section{6. わが国のノックアウトマウスプロジェクト}

現在，マウスには少なくとも 4 種類の亜種が存在し ている。それらは, Mus Musculus Domesticus, Mus Musculus Castaneus, Mus Musculus Musculus, および Mus Musculus Molossinusである. Domesticusは, 欧米に分布し，現在ほとんどの研究者が用いている実 験用マウス，たとえば $129, \mathrm{C} 57 \mathrm{BL} / 6$ や BALB/c，の 起源は Mus Musculus Domestics という亜種である.
Castaneusは東南アジアに, Musculusは, ロシアか ら中国の東北部に分布している。一方，日本には Mus Musculus Castaneus と Mus Musculus Musculus の雑種である Molossinus が分布している。これらの 亜種は，約 100 万年前に分離したといわれ，ゲノムの 塩基配列も約 $1 \%$ 異なっていることがわかった（図 3). ヒトとチンパンジーの違いが約 $1.23 \%$ といわれている ので，この $1 \%$ の違いは大きいと考えている．また， 60,000 個の BAC クローンもあり，50 万種類の SNP も判明している，幸いなことに，この亜種に属する野 生マウスが，1978 年に国立遺伝学研究所の近くで捕 獲された。森脇たちは，このマウスから近交系化を図 り，MSM/Ms と名づけた。現在までにすでに 80 代 となっている，表現型には，特徴的なものがあり，自 発運動は活発で，エネルギー代謝も節約型で，がん等 の疾患に対して抵抗性である。つまり，がんが好発す る実験用マウスとはかなり異なっている。この MSM/Ms とは異なるが，やはり molossinus 由来の $\mathrm{JF} 1$ も樹立されている．筆者らは，これらのマウスか らの $\mathrm{ES}$ 細胞の樹立に成功し, 生殖系列への伝達も確 認した。我が国としては, 独自性のあるプロジェクト が求められており, MSM/Ms 由来の $\mathrm{ES}$ 細胞を用い ることが必要であると思われる。

\section{7. 熊本大学生命資源研究・支援センターの活動}

\section{1) 目標}

5つの目標を掲げている.すなわち，(1)遺伝子改変

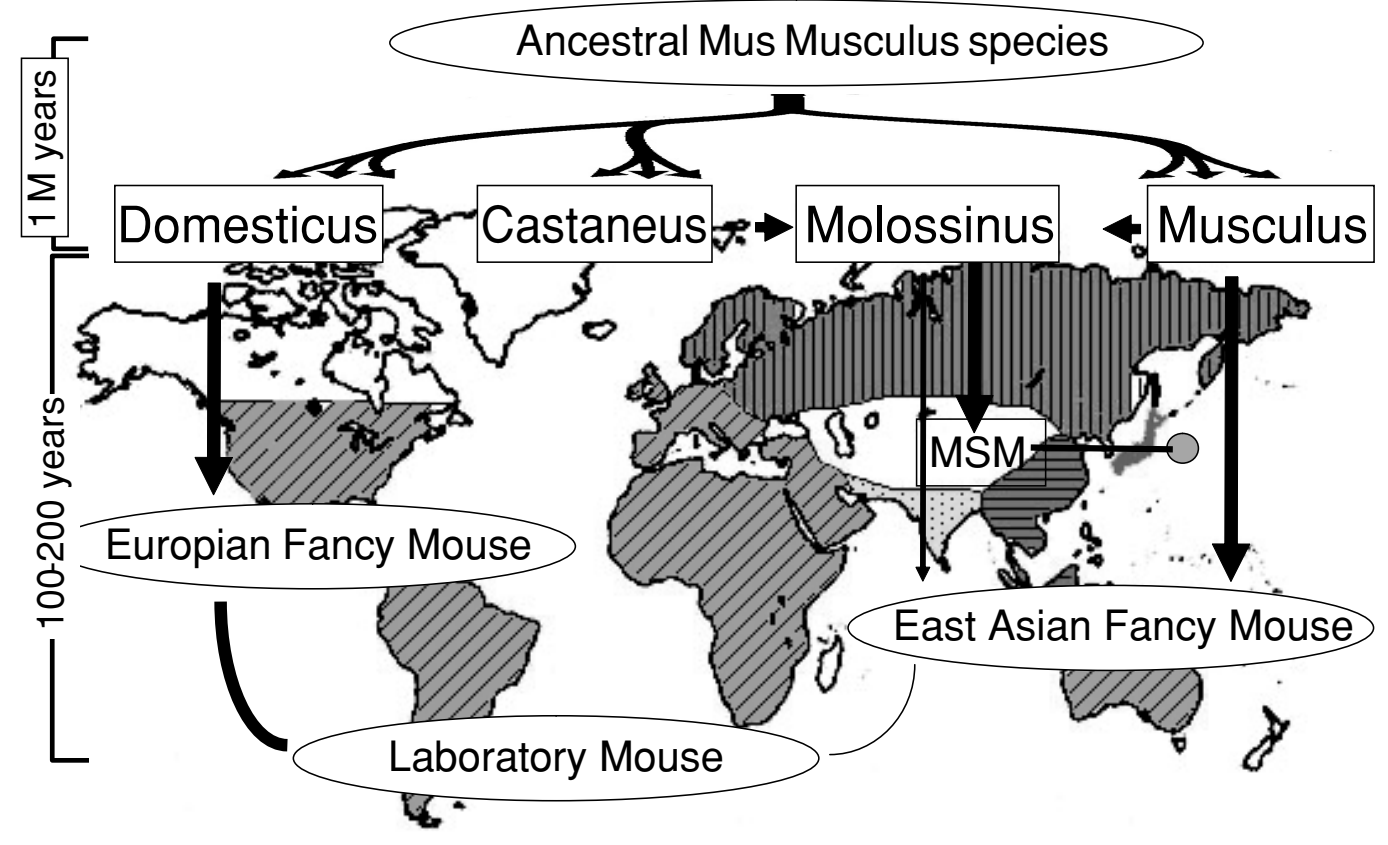

図 3 マウスの起源と亜種 (Moriwaki K. Genetics in Wild Mice. 1994 より改編) 
マウスの作製，保存，供給の一体化を目指し，かつア ジア独自のリソースの確立も目指す，(2)技術の陳旧化 を防ぐため, 遺伝子改変マウスの作製, 保存, 供給に 関する技術開発を行う，(3)マウスのやり取りによる感 染リスクを低減あるいは撲滅するため, 凍結肧および 精子による供給体制の確立を目指す, (4)凍結肧および 精子による供給体制の確立のため, 講習会の実施等に よる人材育成を行う，(5マウスリソースの活用のため, 国内抢よび国際的なネットワーク形成を行う，である.

\section{2）遺伝子改変マウスの作製について}

(1)独自リソースの開発

可変型遺伝子トラップ法を用いて，トラップ ES クローンの収集とトラップマウスの樹立を行ってい る.マウスまで樹立できたものについて，すでに立 ち上げた EGTC (exchageable gene trap clone) デ ータベースに, 順次組み入れている。また, アジア 独自のリソースの開発のため, $\mathrm{MSM} / \mathrm{Ms}$ 由来の $\mathrm{ES}$ 細胞の樹立を行い，これを用いた遺伝子導入お よび破壊マウスの作製を行いつつある。

(2)受託による遺伝子改変マウスの作製

研究者からの依頼を受け, 毎年平均 70 件程度の 遺伝子改変マウスの作製を行っている．また， ES 細胞の講習会も行っているが, 最近は希望のある講 習内容が多様化しており, 個別に対応することにし ている。

\section{3）凍結保存と関連した研究開発}

(1) C57BL/6 マウスの精子は, 従来の方法では凍結に より受精率が $20 \%$ と低かった。 そこで, 高い受精 率が得られる新規凍結保存液を開発した。これによ り受精率が約 $60 \%$ と各段に向上したので, 企業を 通し FERTIUP という商品名で発売を開始した。

(2)マウス胚や配偶子の凍結保存法はルーチン化してい るが, 輸送において液体窒素とそのタンクが必要で あり, 小型化したとはいえ, 輸送の準備, 輸送元か ら輸送先へタンクを送るコストのみならず，輸送先 から輸送元へタンクを送り返すコストがかかる。 そ こで，ドライアイス詰めにした発泡スチロールでの マウス精子の輸送法, さらに, 凍結乾燥精子による 保存法の開発を行っている。

(3)生殖工学の技術を解説した生殖工学マニュアルの $\mathrm{CD}$ 版（日本語, 英語, 中国版）を作成し, 販売し ている.

4）受託による凍結保存, 供給, クリーニング

毎年 100 件を超える系統収集と凍結保存を行ってい る.

5) 微生物学的統御
外部からのマウスは，すべてアイソレーターに収容 し，一定期間飼育し感染がない場合にのみ，一般飼育 室に移すこととしている，また，遺伝子を注入した受 精卵やキメラ肧を移植した仮親は，アイソレーターに て飼育し, 感染のないことを確認した後, 搬出する態 勢をとっている.

CARD 搬出時の検查項目は, Mouse hepatitis virus, Sendai virus, Citrobacter rodentium, Clostridium piliforme, Corynebacterium kutscheri, Helicobacter hepaticus, Mycoplasma spp., Pasteurella pneumotropica, Salmonella spp., Aspiculuris tetraptera, Giardia muris, Syphacia spp., Spironucleus muris, Trichomonas spp., Ectoparasite である。

6) 講習会

毎年 2 回の生殖工学技術講習会を行い, 技術の普及 を行っている。

7) データベース

(1) CARD R-BASE

国立遺伝学研究所の山崎博士, 浜松医科大学の加 藤博士の協力の下, CARD R-BASE を立ち上げ, 凍 結保存しているマウス系統に関する情報を公開して いる. FIMRE 参加機関等のデータベースを統合し た IMSR（international Mouse Strain Resources）が 構築された (http://www.informatics.jax.org/imsr/ index.jsp).

(2) EGTC データベース

可変型遺伝子トラップ法を用いて作製した ES ト ラップクローンについて, EGTC を作成し公開して いる. International Gene Trap Consortium の参加 機関で, 統合データベースが構築された（http:// www.igtc.ca/FAQ.html）（13）.

\section{8) 国際活動}

(1) Federation of International Mouse Resources (14) この設立に参加し，国際間でのマウスリソースの 保存供給のネットワークの形成を行いつつある (http://www.informatics.jax.org/imsr/fimre.html).

(2) AMMRA

アジアでのマウスリソースの開発と保存供給のネ ットワーク形成のための活動を行い，2006 年 11 月 22 日一 24 日に中国上海において, 北京大学生命科 学学院, 協和医科大学・中国医学科学院, 上海生命 科学院上海実験動物センター, 上海模式生物研究セ ンター, 南京大学模式動物研究センター, 台湾実験 動物センター, 韓国生物科学・バイオテクノロジー 研究所, シンガポールリソースセンターとの間で連 合体を形成した。 


\section{文献}

1) Casadaban MJ, et al. Proc Natl Acad Sci USA. 1979;76:45304533.

2) Fried M, et al. Proc Natl Acad Sci USA. 1983;80:2117-2121.

3) O'Kane CJ, et al. Proc Natl Acad Sci USA. 1987;84:91239127.

4) Allen ND, et al. Nature. 1988;333:852-855.

5) Kothary R, et al. Nature. 1988;335:435-437.

6) Gossler A, et al. Science. 1989;244:463-465.
7) Shigeoka T, et al. Nucleic Acids Res. 2005;33:e20.

8) Araki K, et al. Nucleic Acids Res. 1997;25:868-872.

9) Araki K, et al. Cell Mol Biol. 1999;45:737-750.

10) Araki K, et al. Nucleic Acids Res. 2002;30:e103.

11) Auwerx J, et al. Nat Genet. 2004;36:925-927.

12) Austin C, et al. Nat Genet. 2004;36:921-924.

13) Nord AS, et al. Nucleic Acids Res 34(Database Issue). 2006; D642-D648.

14) FIMRe Board of Directors. FIMRe. Mammalian Genome. 2006;17:363-364.

著者プロフィール

山村 研一(やまむら けんいち)

熊本大学 発生医学研究センター・臓器形成分野, 教授, 医学博士.

$\diamond 1973$ 年 3 月信州大学医学部卒業, ’78 年 3 月大阪大学大学院医学研究科博士過程修了 (医学博士), 同年 4 月富山 医科薬科大学和漢薬研究所助手 (病態生化学部門), 同年 10 月米国 Yale 大学 Department of Biology 研究員, '80 年 10 月富山医科薬科大学和漢薬研究所助手 (復職), ’ 81 年 4 月大阪大学医学部助手 (老年病医学講座), ’84 年 7 月同 上講師, ’86 年 4 月熊本大学医学部 教授, ’00 年 4 月熊本大学発生医学研究センター 教授 (改組に伴う配置替)。 ○研究テーマ: 哺乳類の発生と疾患発症に扔ける遺伝と環境の相互作用. 趣味：シュノーケリング. 主な著書：

1. 山村研一. 考える遺伝学. 南山堂；1997 年 2 月 pp1-180.

2. 森脇和郎, 山村研一, 米川博通編集. モデル動物の作製と維持. Life-Science Information Center ; 2004 年 7 月.

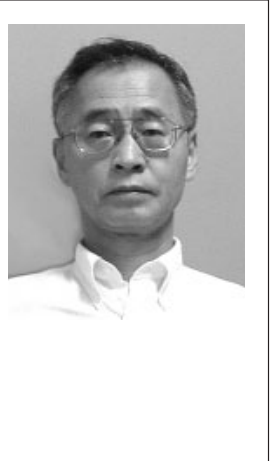

